\title{
The Impact of Mother Tongue on Students' Achievement in English Language in Junior Secondary Certificate Examination in Western Nigeria
}

\author{
DavidAdebayo Oluwole \\ Department of Guidance \& Counselling, University of Ibadan, Ibadan, Nigeria
}

KEYWORDS Mother tongue; students' achievement; English language; Nigeria

\begin{abstract}
The study is designed to examine the influence of mother tongue on Students performance in English language in Junior School Certificate Examination. The study investigated if mother tongue is solely the cause of the students' woeful performance in English Language in Junior School certificate Examination or if there are other complementing factors. The subjects for the study were one hundred male and female SSI students drawn from various government schools in western Nigeria. Using simple percentage descriptive statistic, the research questions that were raised analysed. The findings reveal that mother tongue influences the students' poor performance in English language in Junior School Certificate examination and that there are other factors contributing to students' poor performance in English language. These other factors are poor method of teaching, lack of textbooks, language background and lack of professional growth and development of teachers. Measures that could be taken to enhance students' achievement in every aspect of English language are suggested also. The respondents' age ranged between 10.52 and 15.17. The participants were those who have sat for the Junior Secondary School Certificate examination. They were randomly selected across diverse religious and socio-economic background.
\end{abstract}

\section{INTRODUCTION}

The importance of English language acquisition as a stepping-stone for proficiency in other school subjects cannot be over emphasized. The knowledge is important both for educational, economical and national development of a country.

The importance of English language as a school subject derives mainly from its utilitarian value to the larger Nigerian society. English is the official language of administration and commerce. It is major language of science. Above all, Salami (2002) had emphasized the importance of the use of English language in improving communication among the various ethnic groups in Nigeria. He further highlighted the need for improving the quality of spoken and written English language among school children.

However, one of the current educational problems of public interest is that of poor level of achievement especially in public examinations (Kolawole 1998, Kolawole and Dele 2002). This problem of underachievement among school children has persisted in many subject areas such as Mathematics, English and Science (Ivowi, Okebukola, and Oladotun, 1992; Falayajo, 1997). This poor level of achievement in many subject areas may be due to poor foundation in English language at the primary school level. There are also several research reports, which support the view that language inefficiency invariably leads to poor academic performance (Ayodele, 1988; Falayajo, 1997). No wonder why today, according to Iroegbu (2006) much emphasis is placed on the passing of English language at credit or distinction level in addition to other subjects to enable any candidate gain admission into any Nigerian Higher Institution of learning or be placed well in a good white collar job.

In recognition of the importance of English language for enhancing educational attainment as well as for improving communication ability of citizens, the government had made the subject a core subject (FGN, 2004). It is also compulsory for students to have credit in English language before entering the university. This also explains why many parents go off their way to see that their children pass at credit level or above in English language.

The importance of English language as a school subject derives mainly from its utilitarian value to the larger Nigerian society. English is the official language of administration and commerce. It is major language of science. Above all, Salami (2002) had emphasized the importance of the use of English language in improving communication among the various ethnic groups in Nigeria. He further highlighted the need for improving the quality of spoken and written English language among school children.

However, one of the current educational 
problems of public interest is that of poor level of achievement especially in public examinations (Kolawole 1998, Kolawole and Dele 2002). This problem of underachievement among school children has persisted in many subject areas such as Mathematics, English and Science (Akpan, Ivowi, Okebukola, and Oladotun, 1992; Falayajo, 1997). This poor level of achievement in many subject areas may be due to poor foundation in English language at the primary school level. There are also several research reports, which support the view that language inefficiency invariably leads to poor academic performance (Oluikpe, 1979; Ayodele, 1988; Falayajo, 1997; Onukaogu and Arua, 1997; Onukaogu, 2002).

Okoro (2000) has stated that the problem of poor level of achievement of primary school children was a serious one in Nigeria and this was in spite of the fact that Nigeria had set up goals for increasing minimum level of learning by 1995 . The author had observed that ample evidences of poor performance were still observed as the pupils move up the system. Attempt was therefore made to find out the extent to which Okoro's (2000) observation applies to primary school English Language beyond the year 2000.

Perhaps the way English language is taught in schools and colleges may be blamed for some of the observed lapses in English language achievement and skills of learners. Ubahakwe (1991), Ohia (1997) and Duff (1997) had criticized the traditional teaching strategy for use in English language classrooms. Kolawole $(1991,1998)$ had blamed the use of traditional teaching strategy for lack of good grasp of basic skills in writing. Williams (1990) had described this teaching strategy as a hit and miss affair. Oglan (1997) had criticized the domineering nature of traditional teaching strategy which renders learners passive in class. He therefore recommended an activity classroom where learners especially at the primary school level, can make learning a fun. Such learning activities may include learning with objects, things, photographs, films etc.

Kolawole (2002) also confirmed that the performance of the primary school pupils in English language was very poor. They stressed further that the standard was poor due to a number of other reasons such as:

1. the use of tribal language in the lower classes of the primary school;

2. some pupils do not understand the grammar because their teachers themselves do not know it; and
3. in most cases English language teachers in the senior primary schools resort to the use of mother tongue to teach and explain the English language even up to the secondary school level.

These researchers are of the opinion that there should be a review in the language policy on education. The review according to them should contain recommendations that will make pupils to have exposure to the subject quite early from the primary school irrespective of the advantages of mother tongue. They further suggested that teaching and learning of English should be more practical in our schools, and also the number of years of study and teaching periods should be increased. Finally, materials for learning the subject should be supplied. This will be the time when the problem of failure in the subject will hopefully be overcome. So a firm foundation in English language is very important for better performance.

However, Akinbote and Ogunsanwo (2003) have a different view on the use of English language in the early years of the primary school. They opined that the use of mother tongue in the process of teaching and learning in the early years helps, not only to preserve and value one's culture but also to develop it lexically. According to the authors the use of English language in the early primary school makes the average primary school child unable to be sufficiently literate in either the mother tongue or English language. They felt that to use English language at that level will lead to the children having a mental translation of all concepts presented in English language to their mother tongue in order to gain sufficient meaning of the concepts presented. These researchers believe that a citizen that is literate even only in the mother tongue will be sufficiently equipped to live a useful life in the fast changing world. So if permanent literacy is to be promoted in the primary schools the use of the mother tongue as the medium of instruction in schools ought to be encouraged.

Harker (2000) investigated gender differences in achievement of boys and girls in schools in New Zealand. The study which employed a large sample of 5300 pupils showed that the achievement of girls in English language was significantly higher than that of boys both in terms of mean curriculum coverage and examination learning outcomes. The results however showed that boys achieved significantly better results than girls in Mathematics. The result further revealed that there 
were no significant difference in the achievement of boys and girls in Science (Okeke, 2004). Ivowi, Okebukola, Oludotun and Akpan (1992) showed that English language and literature achievements by Nigerian Junior Secondary School Students is very poor (Ivowi, et al, 1992; Okoro, 2000). Primary school children in the age range of (6-11yrs) need to improve level of their achievement or atleast the number achieving minimum standard. This target has not been met (Okoro, 2000).

Although English language retains its dominant position in the education delivery system in Nigeria, the thrust of our educational language policy is the use of the mother tongue or the language of the immediate community in pre-primary and primary education. Interestingly, private educational entrepreneurs provide preprimary education exclusively through the medium of English language. The mother tongue medium education at the primary school level is provided in less than twenty Nigerian languages throughout the country. English is the exclusive medium of instruction at the junior and senior levels of secondary school education.

Several scholars have addressed the core problems of communicative competence in the use of English language as L2 and its use as the main language of instruction in Nigeria's education delivery process. It is unfortunate that most school leavers (apart from the products of elite private schools) do not possess the required competence in the four language skills for both cognitive and communicative functions.

Statistics released by the West African Examination Council, which conducts the West African Senior Secondary Certificate Examination, show that less than ten percent of secondary school leaver passes in English language at credit level. At the tertiary level of education students have so much difficult with their communicative skills in English that they cannot function effectively in the academic use of English (Okoro, 2000).

There is no doubt that there is a great diversity of varieties and functions of English in Nigeria. For example, it is extensively used in both the electronic and the print media, in the judiciary, the police, the armed forces, the legislative, etc and as a lingua franca in political mobilization, ethical orientation and population education. This confirms the entrenchment of English as the dominant official language of Nigeria. The nagging problem however concerns the quality of English that is taught and used in the school system. The concern being expressed in informed educational circles is the extent to which the variety and quality of English being learned and used in the school system can serve in achieving Nigeria's educational goals and the objectives.

Mother tongue therefore, is defined as the language which a group of people considered to inhabitants of an area acquired in the early years and which eventually becomes their natural instrument of thoughts and communication( You may wish to re-consider other definition of language (Awoniyi, 1978). Mother tongue is the first language that a person learned. In terms of that view, the person is defined as a native speaker of the first language, although one may also be a native speaker of more than one language if all of the languages were learned without formal education, such as through cultural immersion before puberty. Often a child learns the basics of the first language(s) from family (Wikipedia, 2007).

It is therefore generally accepted that in teaching and learning processes, the mother tongue of the child is of utmost importance. For one thing, it categorizes a large part of the child's environment, that is, it has names for most of the objects, actions, ideas, attributes and so on that are so important to him, as well as to any society. In many developing countries today, this is either local language or the language of the previous colorizing power. The mother tongue is the child's environment and is the natural basis on which verbal skills can be built, children learn through communicating in a language, which they understood.

It was in recognition of the importance and contributions of mother tongue to education that made the Federal Ministry of Education in Collaboration with other educational statutory agencies include in the National Policy on Education published in 1977, revised in 1981, the use of mother tongue as a medium of educating pupils at the pre-primary and primary level throughout the country.

According to the National Policy on education published in 1977 revised in 1981, Section 2(ii) which stated that

"Government will ensure that the medium of instruction will be principally the mother tongue or the language of the immediate community"

also in section $3(\mathrm{xx})$ of the same National Policy on Education stated that: 
"Government will see to it that the medium of instruction in the primary school is initially the mother tongue of the immediate community and at a later stage English".

The importance of Nigerian language in the educational process is stated in section 1.

"In addition to appreciating the importance of language in educational process, and as a means of preserving people's culture, the government considers it $n$ the best interest of national unity that each child should be encouraged to learn one of the three major languages other than his mother tongue"

The mother tongue therefore, is a part of the Nigerian culture; it conveys or transmits culture and itself in subjects to culturally conditioned attitudes and beliefs (Awoniyi, 1975). The positive results of the experiment in Mother Tongue Medium in Yoruba carried out at the then University of Ife empirically demonstrated the great advantages of mother tongue in primary education for scholastic attainment (Bamgbose, 1984) and even in the successful mastery of English as a second language.

At this juncture, it is very imperative to look at whether mother tongue has bearing on the English language usage among the secondary school students. It is important to draw attention to the presence of the problems and to, on the basis of what will be found out, recommend what could be done to reduce them if they cannot be totally eradicated.

\section{Research Questions}

The following research questions will be used in:

a. Does mother tongue interference have influence on the written and spoken English of secondary school students?

b. To what extent would the students' parents and home environment explain the influence of mother tongue on English language?

\section{METHODOLOGY}

Research Design: The study is a survey research designed to examine the influence of mother tongue on the English performance of students in J.S.C.E Examination, at twelve randomly selected secondary schools in Abeokuta and Ijebu Zones of Ogun state.

Population and Sample: The target population of this study was Senior Secondary
School Students who participated in the last J.S.C examination. The investigation was carried out in the following selected secondary schools in Abeokuta and Ijebu Zones of Ogun state. Twelve (12) schools were selected while 100 students of current SSI students were randomly selected. The schools selected were those that have been presenting candidates for the Junior Secondary Certificate examination (J.S.C.E) for the past ten years. These schools were considered eligible to participate in this study. The respondents' age ranged between 10.52 and 15.17 . The participants were those who have sat for the Junior Secondary School Certificate examination. They were randomly selected across diverse religious and socio-economic background.

Subjects: The subjects of the study totaling hundred (100) were drawn from S.S. 1 students in the five schools under the study. The students of these schools were selected randomly from all departments of S.S.1 that is Science, Art, and Commercial in each school.

Hundred were used with twenty from each school. The subjects were chosen from the schools by simple random sampling method in such a way that they were representative of the total population of S.S.1 students in each school.

The table 1 shows that $35 \%$ of the respondents used was male while the remaining $65 \%$ were female respondents.

Table 2 shown above indicates that $55 \%$ of the respondents used were between the ages of 14 and 15, 30\% were between 16 and 17 years while the remaining $15 \%$ were respondents between 18 and 19 years.

Table 1: Distribution of respondents by gender $($ No $=100)$

\begin{tabular}{lcc}
\hline Gender & Frequency & Percentage \\
\hline Male & 35 & 35.0 \\
Female & 65 & 65.0 \\
\hline Total & 100 & 100.0
\end{tabular}

Table 2: Distribution of respondents by age

\begin{tabular}{lcc}
\hline Age & Frequency & Percentage \\
\hline $14-15$ years & 55 & 55.0 \\
16-17years & 30 & 30.0 \\
18-19years & 15 & 15.0 \\
\hline Total & 100 & 100.0 \\
\hline
\end{tabular}

The table 3 shows that all the respondents used for the study were from S.S.1 
Table 3: Distribution of respondents by class

\begin{tabular}{lll}
\hline Class & Frequency & Percentage \\
\hline S.S.I. & 100 & 100.0 \\
Total & 100 & 100.0 \\
\hline
\end{tabular}

Table 4 shows that $30 \%$ of the respondents are in science class, $45 \%$ are in art class while $25 \%$ are in commercial class.

Table 4: Distribution of respondents by class

\begin{tabular}{lcc}
\hline Class & Frequency & Percentage \\
\hline Science & 30 & 30.0 \\
Art & 45 & 45.0 \\
Commercial & 25 & 25.0 \\
\hline Total & 100 & 100.0 \\
\hline
\end{tabular}

Analysis of the table 5 shows that $4 \%$ of the respondents have (A) in English Language, 6\% have (B), $90 \%$ have (c) while $0 \%$ have $(\mathrm{P})$ and $(\mathrm{F})$.

Table 5: Distribution of respondents by grades in English in junior school certificate examination

\begin{tabular}{lcc}
\hline Gender & Frequency & Percentage \\
\hline A & 4 & 4.0 \\
B & 6 & 6.0 \\
C & 90 & 90.0 \\
P & - & 0.0 \\
F & - & 0.0 \\
\hline
\end{tabular}

Instrumentation: Mother Tongue Effect on English language Scale (MTEES) was a self reported scale that was designed by the researcher. This was to elicit information on how mother tongue influences English language performance of students in Junior Secondary Certificate Examination. The questionnaire was drawn in order to obtain data for the study. The questionnaire consists of a total number of twenty (20) items. Using test retest reliability method, the alpha coefficient of the test was 0.78 .

Method of Data Analysis: The data collected were analysed using simple percentages. Simple percentage is the most widely used descriptive statistic which could yield valuable quantitative and qualitative results. Qualitative results in the sense that it is the basis of graphic illustrations such as pie chart, bar chart and histogram. Simple percentage is relevant in quantitative illustration because it is useful in simple explanation of basic differences or similarities that could exist between or among the variables under observation.

\section{RESULTS}

This section shows that analysis of results of each item contained in the questionnaire administered on the respondents.

This distribute indicates $75 \%$ do not avoid English language, $5 \%$ avoid it while $20 \%$ were undecided (Table 6).

Table 6: The responses of the students or avoidance of English language despite the fact that subject.

\begin{tabular}{lllll}
\hline Respondents & Yes & No & Undecided & Total \\
\hline 100 & 5 & 75 & 20 & 100 \\
Percentage & 5.0 & 75.0 & 20.0 & 100.0 \\
\hline
\end{tabular}

Ninety five percent consider English language a difficult subject while $5 \%$ do not consider it a difficult subject to understand (Table 7).

Table 7: The responses of students on if they consider English language a difficult subject

\begin{tabular}{lllll}
\hline Respondents & Yes & No & Undecided & Total \\
\hline 100 & 95 & 75 & 0 & 100 \\
Percentage & 95.0 & 75.0 & 0.0 & 100.0 \\
\hline
\end{tabular}

Observation at table 8 shows that $75 \%$ admit that their mother tongue hinders their interest in English language while $25 \%$ do not agree that mother tongue hinders interest in English language.

Table 8: The responses on if mother tongue hinders respondent's interest in English as a subject.

\begin{tabular}{lllll}
\hline Respondents & Yes & No & Undecided & Total \\
\hline 100 & 75 & 25 & - & 100 \\
Percentage & 75.0 & 25.0 & 0.0 & 100.0 \\
\hline
\end{tabular}

Findings on item (d) indicate that $90 \%$ do not prefer Yoruba Language to English Language as a subject while $10 \%$ prefer Yoruba language to English language (Table 9).

Table 9: The responses of respondents on if they prefer Yoruba Language to English language as a subject

\begin{tabular}{lllll}
\hline Respondents & Yes & No & Undecided & Total \\
\hline 100 & 10 & 90 & - & 100. \\
Percentage & 10.0 & 90.0 & - & 100.0 \\
\hline
\end{tabular}


Ten percent of the respondents admit the score higher in Yoruba language while 90\% do not score higher in Yoruba language or score lesser in it (Table 10).

Table 10: The responses on if respondents score higher in Yoruba language than in English language

\begin{tabular}{lllll}
\hline Respondents & Yes & No & Undecided & Total \\
\hline 100 & 10 & 90 & - & 100 \\
Percentage & 10.0 & 90.0 & - & 100.0 \\
\hline
\end{tabular}

Findings show that $65 \%$ prefer watching and listening to television and radio programmes in English language while 35\% do not prefer English programmes (Table 11).

Table 11: Percentage of respondents that prefer watching and listening to television and radio programmes in English language to Yoruba language

\begin{tabular}{lllll}
\hline Respondents & Yes & No & Undecided & Total \\
\hline 100 & 65 & 35 & - & 100 \\
Percentage & 65.0 & 35.0 & 0.0 & 100.0 \\
\hline
\end{tabular}

Findings show that $90 \%$ of respondents are keen to master English language while $10 \%$ are not keen (Table 12).

Table 12: Shows responses on if students are keen to master English Language to perfection.

\begin{tabular}{lllll}
\hline Respondents & Yes & No & Undecided & Total \\
\hline 100 & 90 & 10 & - & 100 \\
Percentage & 90.0 & 10.0 & - & 100.0 \\
\hline
\end{tabular}

Ninety percent of the respondents agreed that English Language can be improved with good method of teaching while $10 \%$ disagreed (Table 13).

Table 13: Indicates the responses of respondents on the belief that their English Language can be improved with good method of teaching.

\begin{tabular}{lllll}
\hline Respondents & Yes & No & Undecided & Total \\
\hline 100 & 90 & 10 & - & 100 \\
Percentage & 90.0 & 10.0 & - & 100.0 \\
\hline
\end{tabular}

The table 14 shows that $80 \%$ of respondents parents do not interact with them at home in English language while only $20 \%$ of respondents parents interact in English language

Fifty five percent of the respondents agree that teacher's method of teaching influences ability to compre-hend English language as a subject while $45 \%$ do not agree that it influences comprehension of English language (Table 15).
Table 14: Indicates percentage of respondents whose parents interact in English Language at home.

\begin{tabular}{lllll}
\hline Respondents & Yes & No & Undecided & Total \\
\hline 100 & 20 & 80 & - & 100 \\
Percentage & 20.0 & 80.0 & 0.0 & 100.0 \\
\hline
\end{tabular}

Table 15: shows responses on the influence of teacher's methods of teaching on respondent's ability to understand English Language.

\begin{tabular}{lllll}
\hline Respondents & Yes & No & Undecided & Total \\
\hline 100 & 55 & 45 & - & 100 \\
Percentage & 55.0 & 45.0 & - & 100.0 \\
\hline
\end{tabular}

This table 16 indicates that $90 \%$ of respondents feel comfortable in the midst of friends who speak English Language fluently while $10 \%$ do not feel comfortable because of their inability to meet the standard of their friends.

Table 16: Indicates percentages of Students who feel comfortable in the midst of friends who speak English language fluently.

\begin{tabular}{lllll}
\hline Respondents & Yes & No & Undecided & Total \\
\hline 100 & 10 & 90 & - & 100 \\
Percentage & 10.0 & 90.0 & - & 100.0 \\
\hline
\end{tabular}

Ninety percent indicate that they are conscious of errors made when interacting in English language while 10\% are not conscious of it at all (Table 17).

Table 17: The response on if respondents are conscious of errors made when interacting in English language

\begin{tabular}{lllll}
\hline Respondents & Yes & No & Undecided & Total \\
\hline 100 & 10 & 90 & - & 100 \\
Percentage & 10.0 & 90.0 & - & 100.0 \\
\hline
\end{tabular}

Analysis shown in table 18 above indicates that $65 \%$ of the respondents prefer to interact with their friends in mother tongue while $35 \%$ do not prefer it.

Table 18: The responses of students on if they consider English Language a difficult subject

\begin{tabular}{lllll}
\hline Respondents & Yes & No & Undecided & Total \\
\hline 100 & 65 & 35 & 0 & 100 \\
Percentage & 65.0 & 35.0 & 0.0 & 100.0 \\
\hline
\end{tabular}


Sixty five percent of the respondents do not want English lesson to be translated into mother tongue while $85 \%$ want to done (Table 19).

Table 19: The response on if respondents would like English Lesson to be translated into their mother tongue for easier comprehension

\begin{tabular}{lllll}
\hline Respondents & Yes & No & Undecided & Total \\
\hline 100 & 35 & 65 & - & 100 \\
Percentage & 35.0 & 65.0 & - & 100.0 \\
\hline
\end{tabular}

This table 20 clearly shows that $75 \%$ of respondents find English Grammar difficult than other aspects of English Language while 25\% do not find it difficult.

Table 20: The percentage of respondents who find Grammar difficult in English language

\begin{tabular}{lllll}
\hline Respondents & Yes & No & Undecided & Total \\
\hline 100 & 75 & 25 & - & 100 \\
Percentage & 75.0 & 25.0 & - & 100.0 \\
\hline
\end{tabular}

Sixty percent $\mathrm{f}$ the respondents indicate that mother tongue affects their composition while $40 \%$ do not agree that it affects their composition (Table 21).

Table 21: The responses of students if they consider English Language a difficult subject

\begin{tabular}{lllll}
\hline Respondents & Yes & No & Undecided & Total \\
\hline 100 & 60 & 40 & - & 100 \\
Percentage & 60.0 & 40.0 & - & 100.0 \\
\hline
\end{tabular}

\section{DISCUSSION}

From Table 6, critical analysis of this table shows that majority of the students avoid English language because of much emphasis placed on the passing of the subject at credit or distinction level to enable any candidate gain admission into any Nigerian Higher Institution of learning. Also, majority of the respondents consider English Language a difficult subject because of their inability to understand every aspect, which English language entails. Moreover most of the respondents come from an environment where English language is not the medium of communication. Observation made on table 8 indicates that mother tongue has a strong pull on English language. The level of infiltration of mother tongue into the respondents' English is very high. Attention of the researcher was drawn to a student who was trying to construct a sentence such as "I was dancing very good and people were gumming money on my front head:

All these semantic mistakes were owing to mother tongue interference.

Table 9 result has clearly shown that majority $(90 \%)$ of the respondent prefer English language to Yoruba language is not a core subject especially for science and commercial students. Moreover, much emphasis is not placed on it as a "gateway" to the university.

Table 10, 90\% of the respondents score higher in English Language because it is a core subject and Yoruba language proves difficult to understand.

Table 11, the respondents' high preference $(65 \%)$ of watching and listening to television and radio programme in English language portrays their interest to improve their competence in English language.

Majority of them believe that most educative programmes like schools debate, current affairs, nutrition reports, health talk and soap operas are broadcast in English language and these will widen their horizon. Table 12 results here buttress the facts stated in tables 11 .

Table 13, findings here show that $90 \%$ agree that their English language can be improved with good method of teaching. This could be complimented with a conducive environment and a small number of students to teacher ratio, to improve the teaching and learning process.

Table 14, A Critical analysis of this table shows that inability of parents to speak or express themselves in English language has immensely contributed to students' poor academic performance in English language this might result from parents' poor educational background.

Table 15, indication from this table shows that good method of teaching employed by teacher can enhance better comprehension of English language.

Table 16 and 17, buttress the students' willingness to bring their English language to perfection, as this will assist them in their studies.

Table 17, analysis of this table shows that respondents who feel comfortable in the midst of friends who speak English fluently have a good command of English. Interaction with friends in English language will open up their weakness and strength in the language.

On table 18, majority of the respondents $(65 \%)$ do not believe that translation of English lessons to mother tongue can improve their understanding 
of the subject because they perceive their capability in the subject is too bad.

\section{RECOMMENDATION}

These recommendations are made in order to solve some of the problems militating against students' competence in English language in Junior School certificate Examination.

Having discovered that the use of mother tongue in school contributes or influence students performance in English, English language should be used as a medium of communication within and outside the classroom. Both teachers and students should endeavour to improve their proficiency level of the language.

Teachers need to do more than teaching theories in class. Proper method of teaching and appropriate instructional materials should be adopted to compliment teacher's knowledge. This goes a long way in influencing teaching and learning process in English language. Material (s) selected should be commensurable with grade or maturity level of students.

Good reading habit and library study should also be developed in the students. Students should be encouraged to approach reading with alertness and critical mind. They should be made to develop taste for books which are significant in the achievement of good result in English language in Junior School Certificate Examination

Schools should organize debate and essay competitions among students within and outside their schools. Students should also be given the opportunity to explain points and express views in class discussion and any error made should be corrected by the teacher without any intimidation as these will enhance a proper evaluation of learners' performance or progress in English language.

Provision of well-equipped library should be made in the schools and community. Textbooks that are useful in English language should be of great amount in the library to augment students' efforts. Majority of the students lack relevant textbook because of their poor socio-economic background.

Teachers must continually update their knowledge within their discipline. They must keep information about new methods and materials that will make their teaching more effective. These can be achieved by participating in in-service courses, workshops, participating in and attending professional meetings and embarking on postgraduate programmes which can extend their present knowledge as well as expose them to areas within which they had no previous contact.

Above all, if all the recommendations are strictly adhered to, there will be great improvement on students' performance in English language in Junior School certificate Examination.

\section{CONCLUSION}

The findings reveal that mother tongue influences the students' poor performance in English language in Junior School Certificate examination and that there are other factors contributing to students' poor performance in English language. These other factors are poor method of teaching, lack of textbooks, language background and lack of professional growth and development of teachers. On the whole, the performance of students in English language is poor and if the discovered factors are not tackled on time, it will cause a drastic decline in standard of education.

\section{REFERENCES}

Akinbote, Refus Olusegun and V. I. Iroegbu. 2001. "Effect of three modes of Teaching Reading on Primary School Pupils Achievement in English Comprehension." Evaluation Research, 1(3): 3845 .

Ayodele, S.O. 1988. "A Study of the effects of the problems of class sizes and location of schools on performance of pupils." Nigerian Journal of Curriculum Studies. 1(2): 145-152.

Bennelt, W.A. 1973. Applied Linguistic and Language Learning. Cambridge: Cambridge Press Limited.

Craft, K. (Ed). 1980. Reading on English as a Second Language. Toronto: Little Brown.

Duff, A. 1997. Translation. Oxford: Oxford University Press.

Etim, J.S. 1986. "Common Errors in the Written Exercises of Learners of English Language in Nigerian Secondary Schools", (Pp. 33-41.) in S. O. Udoh (ed.), Use of English in Communication. Ibadan: Spectrum Books.

Falayajo, W. 1997. Prototype of National Assessment for Nigeria. UNESCO/UNICEF Monitoring of Learning Achievement Programme.

Harker, R. 2000. "Achievement, gender the single-sex coeducation debate." British Journal of Sociology of Education, 21(2): 204-218.

Iroegbu, V.I. 2006. Effects of Modelling and PictureBased Instructional Strategies on Primary School Pupils' Learning Outcomes in English Language. Ph.D. Thesis Department of Teacher Education, University of Ibadan, Nigeria. XVI + 187pp. 
Ivowi, U.M.O., P. A. O. Okebukola, J. S. O. Oludotun and B. B. Akpan. 1992. "Raising the Standard of performance in public examinations in Science, Technology and Mathematics." Stan Position Paper (4).

Kolawole, C.O.O. 1991. University of Ibadan Postgraduate language students' Evaluation of some Syntactic Errors in written English. An M.Ed Project Department of Teacher Education, University of Ibadan. IX $+81 \mathrm{pp}$.

Kolawole, C.O.O. and A. Dele. 2002. "An examination of the National policy of language education in Nigeria and its implications for the teaching and learning of the English language." Ibadan Journal of Educational Studies, 2(1): 12-20.

Kolawole, C.O.O. 1998. Linguistic Inputs and Three Methods of presentation as Determinants of Students Achievement in Senior Secondary School Essay Writing in Ibadan. Ph.D. Thesis Department of Teacher Education, University of Ibadan, Nigeria. XVI + 187pp.

Oglan, G.R. 1997. Parents, Learning and Whole Language Classrooms. Urbana; Illinois: National Council of Teachers of English.

Ogunsanwo T. 2003. Homework made and Parental Involvement in Homework as Determinants of Primary School Pupils Learning Outcomes in Mathematics in Ibadan North, Ibadan. Ph.D Thesis Department of Teacher Education, University of Ibadan. XIX + 313pp.

Oguntuase, B. 1986. "The English Language Crisis in Nigeria." The National Concord, Saturday, May 17.

Ohia, I.N. 1997. The Lexicon of Standard Nigerian English and Acceptability Paradigm among the Educational Elite. Ph.D Thesis Department of Teacher Education, University of Ibadan. xiii + $200 \mathrm{pp}$.
Okeke, C.O. 2004. "Gendered voices in a Heterogenous classroom: Moving qualitative research forward within the Nigerian Educational research tradition. The African Symposium." An on-line Educational Research Journal. A publication of the African Educational Research Network, 4(2): 1-14.

Okoro, D.C.U. 2000. "Basic Education-emerging issues, challenges and constraints in the state of Education in Nigeria." A publication of UNESCO Nigeria Abuja Office. Pp. 34-51.

Onukaogu, A.E. and A. E. Arua. 1997. "Towards a better understanding of reading", (Pp. 17-28) in A. E. Arua and O.B. Jegede (eds.), Teaching Reading in Nigeria: A Guide to Theory and Practice. Ile-Ife TAWL Centre of Excellence for Literacy and Literacy education in Association with the Reading Association of Nigeria.

Onukaogu, A.E. 2002. "Developing Effective Reading Skills", (Pp. 25-39) .in A. Mansaray and I.O. Osokoya (eds.), Curriculum Development at the Turn of the Century: The Nigerian Experience. Ibadan: Dept. of Teacher Education, University of Ibadan.

Richards, J.C. 1985. The Concept of Language Teaching. London: Cambridge University Press.

Ubahake, E.E. 1979. "Evaluation criteria for language texts". (Pp. 33-47) in E.E. Ubahakwe (ed.), The Teaching of English Studies. Ibadan University Press (I.U.P.) Nigeria.

Weinrich, U. 1993, Language in contact. Findings and Problems. New York: Linguistics Circle of New York.

Wikipedia. 2007. Mother tongue. http://en.wikipedia.org/ wiki/First_language

William, D. 1990. English Language Teaching: An Integrated Approach. Ibadan Spectrum Books Limited. 